De Jong, J., A. van den Burg, and A. Liosi. 2018. Determinants of traffic mortality of Barn Owls (Tyto alba) in Friesland, The Netherlands. Avian Conservation and Ecology 13(2):2. https://doi.org/10.5751/ACE-01201-130202

Copyright (C) 2018 by the author(s). Published here under license by the Resilience Alliance.

Research Paper

\title{
Determinants of traffic mortality of Barn Owls (Tyto alba) in Friesland, The Netherlands
}

\author{
Johan de Jong ${ }^{1}$, Arnold van den Burg ${ }^{2,3}$ and Allan Liosi ${ }^{4}$ \\ ${ }^{1}$ Working Group Barn Owls Netherlands, ${ }^{2}$ Biosphere Science Foundation, ${ }^{3}$ Department of Environmental Science, Radboud \\ University Nijmegen, ${ }^{4}$ Working Group Barn Owls Flevopolder
}

\begin{abstract}
Collisions with vehicles can contribute significantly to overall mortality in many species. We aim to clarify causal factors affecting Barn Owl (Tyto alba) mortality along roads in the Province of Friesland, The Netherlands. Although Barn Owl road casualties have received a lot of attention in the past, relationships with food availability and road design have not been clarified. We quantified breeding densities and reproduction rates, and combined these with road casualty records and characterization of road design. We obtained 996 ring-recoveries of Barn Owls (1994-2009), all of which were found dead in Friesland. All locations were accurate to within 100 meters. Along three routes with minor and major roads we made an inventory of road, verge, and hinterland typology. In two other datasets (539 and 461 birds) we analyzed the relationships between road mortality, body mass, and sex ratio. More than $70 \%$ of all owl casualties were in their first year of life and $15 \%$ in the second year. The highest mortality was in autumn and winter. Sex ratios were equal (232 males, 229 females). Although casualties were on average lighter than live-caught control birds, many of the traffic victims were in good condition. In years of high owl productivity, road mortality was strongly reduced. The number of road victims on major roads was significantly higher than on other road types. Highway junctions and highway-secondary road junctions contributed significantly to the spatial clustering of owl mortality. We conclude that in years when prey availability in the agricultural fields is high, roads/verges are not favored as hunting grounds. Therefore, the best option to reduce owl traffic victims is to improve the quality of farmland as foraging areas, and secondly to make design adjustments at major junctions to reduce owl-traffic collisions.
\end{abstract}

\section{Déterminants de la mortalité d'Effraies des clochers (Tyto alba) attribuable aux véhicules en Frise, Pays- Bas}

RÉSUMÉ. Les collisions avec les véhicules sont une cause importante de mortalité pour de nombreuses espèces. Nous avons cherché à clarifier les facteurs causaux affectant la mortalité d'Effraies des clochers (Tyto alba) le long des routes dans la province de la Frise, PaysBas. Bien que les effraies victimes de véhicules aient reçu beaucoup d'attention dans le passé, les relations entre la disponibilité de nourriture et la conception des routes n'ont pas été précisées. Nous avons quantifié les densités de nidification et les taux de reproduction, et les avons combinés avec les mentions d'effraies heurtées par des véhicules et les caractéristiques des routes. Nous avons récupéré 996 bagues d'effraies (1994-2009), toutes trouvées mortes en Frise; les positions avaient une précision de $100 \mathrm{~m}$. Le long de trois tracés comportant des routes principales et secondaires, nous avons réalisé un inventaire du type de routes, d'accotements et d'arrière-pays. À l'aide de deux autres ensembles de données (539 et 461 oiseaux), nous avons analysé les relations entre les mortalités attribuables aux véhicules, la masse corporelle et le rapport des sexes. Plus de $70 \%$ des mortalités d'effraies sont survenues dans la première année de vie des oiseaux et $15 \%$ dans leur deuxième. Le taux de mortalité le plus élevé est survenu en automne et en hiver. Le rapport des sexes était égal (232 mâles, 229 femelles). Même si les effraies mortes étaient en moyenne plus légères que les oiseaux contrôle capturés vivants, de nombreuses effraies victimes de véhicules étaient en bonne condition. Au cours des années durant lesquelles la productivité d'effraies était élevée, les mortalités par véhicule étaient grandement réduites. Le nombre de mortalités sur les routes principales était significativement plus élevé que sur les autres types de routes. Les intersections d'autoroutes et celles d'autoroutes et de routes secondaires ont grandement contribué au regroupement spatial des mortalités. Nous concluons que durant les années où les proies sont abondantes dans les champs agricoles, les routes et les accotements ne sont pas prisés comme aires de chasse. Ainsi, la meilleure option pour réduire le nombre d'effraies heurtées par des véhicules est d'améliorer la qualité des terres agricoles comme aire d'alimentation, et dans un second temps, de faire des ajustements dans la conception des principales intersections afin de réduire la mortalité d'effraies.

Key Words: Barn Owl; body mass; conservation; dispersal; Friesland (Netherlands); road verge types; road victims; sex ratio; Tyto alba

\section{INTRODUCTION}

Roads have direct and indirect negative impacts on animal populations (Erritzoe et al. 2003, Kociolek et al. 2011, Loss et al. 2014). One of the most noticeable and direct effects are roadkill of birds, which mount up to an estimated 340 million yearly in the USA alone (Loss et al. 2014). In Europe, estimates of annual avian casualties per country reach up to 27 million in the UK (Erritzoe et al.2003). In some species effects of road mortality on population size have been demonstrated (Kociolek et al. 2011). Also, in the Netherlands, collisions with vehicles (roadkill) are a major concern in animal conservation. For example, yearly mortality of pine marten Martes martes, hedgehog Erinaceus europaeus, and 
badger Meles meles amount to 30\% (H. Jansman, personal communication), 9-26\% (Huijser 2000), and 12-17\% (Dekker and Bekker 2010), respectively, of their entire Dutch populations. As such, population growth and dispersal in some species are greatly hampered by road mortalities.

The vulnerability of particular species to traffic depends on behavioral and ecological characteristics. Some species are exceptionally vulnerable to traffic, such as toads Bufo bufo and hedgehogs, which sit still in response to an oncoming vehicle. Especially in the Netherlands, where agricultural fields are intensively managed, road verges provide habitat for small rodents and hence attract predators such as martens and owls. Owls are exceptionally vulnerable to traffic-caused mortality (Bishop and Brogan 2013) because of their low-level hunting flights. Furthermore, owls generally have a low wing loading that increases the chance of being swept onto the road by the air pressure profile of a passing truck, and to be killed by the next passing vehicle.

Sadly, Barn Owls (Tyto alba) are nowadays so common in the Netherlands (up to 1200 breeding pairs in bad vole years and in excess of 3000 pairs in good vole years) that they get killed by traffic in great numbers. Because many birds are ringed, their age and hatching location are often known. Furthermore, in the province of Friesland, the entire Barn Owl population is well studied because by far most pairs breed in nest boxes provided by volunteers, who also monitor nest box occupancy and reproduction. Because breeding densities, young production, and bird origins are often known, it is possible to study the factors governing road mortality in greater detail in Barn Owls compared to any other species. In this paper we examine the occurrence of traffic victims with characteristics of the Barn Owl population, road design, and ecological conditions, to formulate mitigation strategies for owls.

Avian road casualties have been investigated in Europe from the 1930s (Barnes 1936). Many studies involved owls, and the increase in reported owl deaths along roads during the last century closely paralleled the increase of traffic, especially in the second half of the 20th century (Uhlenhaut 1976, Bourquin 1983, De Jong 1983, Bairlein 1985, Marti and Wagner 1985, Illner 1992, Van der Hut et al. 1992, Van den Tempel 1993, De Bruijn 1994, De Jong and Paulusma 1996, Baudvin 1997, Newton et al. 1997, Rodts et al. 1998, Smit et al. 1998, Van Nieuwenhuyse et al. 2008, Ramsden 2009). Among other causes of reported deaths, road deaths of Barn Owls in Britain increased from 6\% in the period 1910-1954 to $15 \%$ in $1955-1969$, to $35 \%$ in $1963-1970$, and up to $50 \%$ in $1991-$ 1996 (Newton et al. 1997). In the Netherlands, roadkill increased from almost $5 \%$ before 1963 to $30 \%$ in the 1980s (De Jong 1995); in the period between 1994 and 2007 the death toll due to traffic amounted to $64 \%$ of all registered deaths. Obviously, these figures cannot be simply translated into percentages of the entire population because other forms of mortality will be underreported (Taylor 1994) and exact population size and numbers of road victims are generally poorly known.

Despite the fact that road casualties have received a lot of attention in the past, relationships with food availability and exact road design have thus far not been clarified. We fill this gap by analyzing statistics from breeding biology in combination with road casualty records, and further subdividing and characterizing stretches of various road types, which also enable us to derive science-based conservation strategies.
Our study includes three complementing approaches to basically analyze the same set of data. We studied the distribution of owl traffic mortality in space and time in relationship with parameters linked to individual birds (age, sex, body mass, distance from natal nest site), population characteristics (total young production per $5 \times 5 \mathrm{~km}$ block and per breeding pair per year), and road layout (primary or secondary road, and characteristics of the central divide, verges, and hinterland). We expected most birds to be of young age (cf. Massemin et al. 1998) and to have a male bias in sex ratio during the breeding season because females tend to the nest while males are hunting. We also expected a preponderance of underweight birds among road casualties, which may be drawn to hunt along road verges because of higher numbers of small mammals. Concurrent with our hypothesis to find mainly young birds, we anticipated that most birds would fall victim close to their natal nest site. The total number of young per unit area is an integrated figure of the number of breeding pairs and breeding success, both showing a positive relationship with habitat quality as experienced by the birds themselves (Taylor 1994). We expected to find more casualties if young production was higher, i.e., habitat quality was better. We also expected a higher number of road victims in good vole years because more young are raised in years when food is plentiful (Taylor 1994). We used average young production per year per pair as indicator of yearly variation in food availability.

In terms of road layout, we anticipated more casualties in areas with a higher density of roads, especially major roads because average speeds are higher and traffic more crowded. Short grassland vegetation is ideal for small rodents and is likely to attract Barn Owls. So, roads with wide verges and divides, and hinterlands dominated by grasslands were expected to give most mortality. As such we also expected to find clustering of Barn Owl casualties at sites that offered the best foraging opportunities.

\section{METHODS}

From 1994 until 2009 we obtained 994 ring recoveries of Barn Owls, ringed as nestlings and found dead as road victims in Friesland (reported by members of the general public and collected by the Dutch Ringing Station; Fig. 1). All birds selected for this study were reported as freshly dead, so the date a bird was found was close to the actual date of mortality (estimated to have deceased within up to seven days before). All locations where birds were found were linked to the closest hectometer post, so location accuracy was within 100 meters. This selection of birds was used to map the geography of owl mortality in Friesland.

Additionally, we carried out a survey along three routes in the province of Friesland: (1) Bolsward-Zurich-Harlingen-Leeuwarden (major roads)-Bolsward (minor road), (2) Drachten-HeerenveenWolvega (major roads)-Oosterwolde-Drachten (minor road), and (3) Buitenpost-Twijzel-Quatrebras-Veenwouden-Dokkum-MetslawierEe-Dokkumernieuwezijlen-Kollum-Buitenpost (minor roads; Fig. 2). Here, we define "major" roads as roads comprising two traffic lanes in each direction, with a speed limit of $120-130 \mathrm{~km} /$ $\mathrm{h}$, and "minor" roads as roads with one traffic lane in each direction, with a speed limit of up to $80 \mathrm{~km} / \mathrm{h}$. Typically, major roads in Friesland have wider roads verges compared to minor roads (examples in Fig. 3). We have made an inventory of the presence of different road verge types, described by the following parameters: the width of the verge and central divide in meters, $\%$ grass cover, and the presence of major highway junctions 
Fig. 1. Distribution of 996 Barn Owl (Tyto alba) road casualties in the province of Friesland, all of which were ringed as nestlings in Friesland in the period 1994-2009.

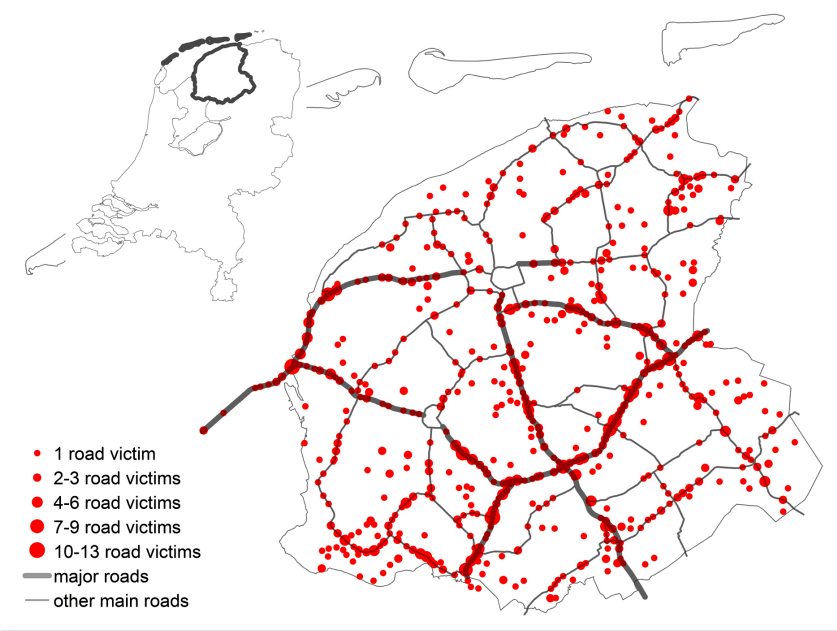

Fig. 2. Study areas of road typology in the Province of Friesland.

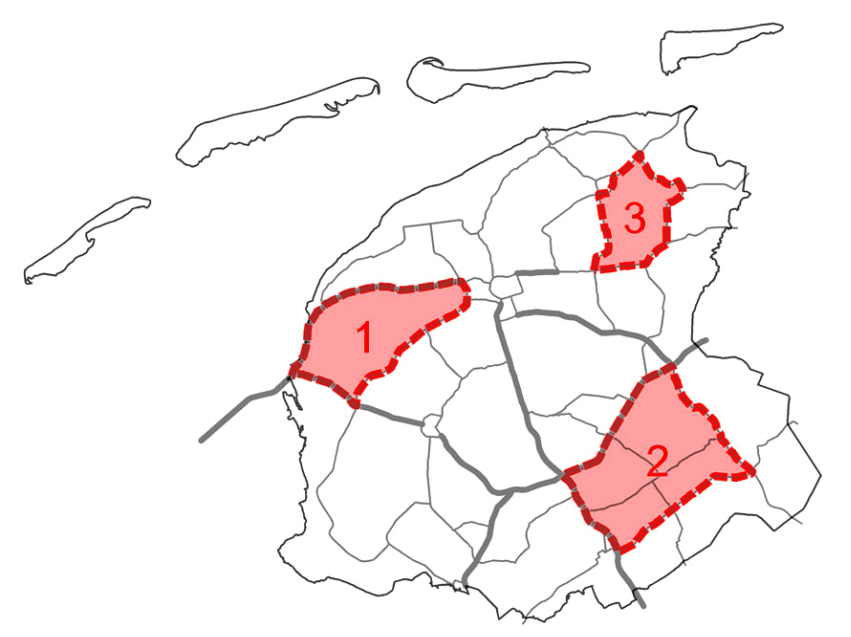

(example in Fig. 3), road exits and entries, and landscape elements along the verge (wood, wooded bank, canal, ditch, dike, and bank within $<30 \mathrm{~m}$ of the road), and typology of the hinterland (the presence of meadows, farmland, lake, built-up area, cultivated land, or nature reserve), and the landscape type according to De Jong (2009). Landscape type is defined by the coverage of small landscape elements, ranging from $0-5 \%$ (landscape type 1$)$ to $>$ $70 \%$ (landscape type 15 ), and, e.g., landscape type 4 indicates $16-$ $20 \%$ coverage. Here "hinterland" is characterized as areas that are $>50 \mathrm{~m}$ from the road edge.

Obviously, the chances of owls getting themselves killed along a road is also dependent on the local traffic volume, especially during the evening and night. The Province of Friesland and the Ministry of Infrastructure and the Environment kindly provided traffic count data for minor and major roads respectively. From the data, we extracted the true measurements (and not the modeled data) that were applicable to minor and major roads in Friesland. The data were grouped into time sections: 7:00 to 19:00 is referred to as daytime, 19:00 to 23:00 as evening, and 23:00 until 7:00 as night. This does not exactly match daylight hours throughout the year, but provides clear indication of how busy the Frisian roads are (Fig. 4).

Fig. 3. Examples of road design in Friesland: (A) minor road, (B) major road with broad verge, (C) junction between a major and minor road, and (D) the same junction as in $\mathrm{C}$, but from aerial view (Google Earth).
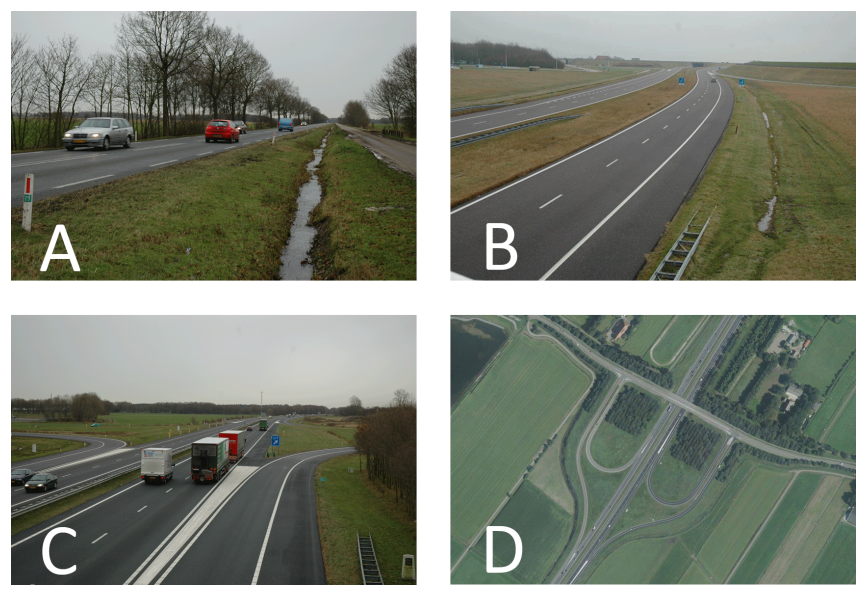

Fig. 4. Traffic volume on Frisian major and minor roads, during different time periods of the day (exact time intervals are given in the text). Every data point represents the yearly average of the available data between 2001 and 2015 (the amount of which varied between years). The $\mathrm{x}$-axis gives traffic volume per hour on a 24-hour basis. The y-axis depicts traffic volume for the indicated time intervals. Data provided by the Province of Friesland and Ministry of Infrastructure and the Environment.

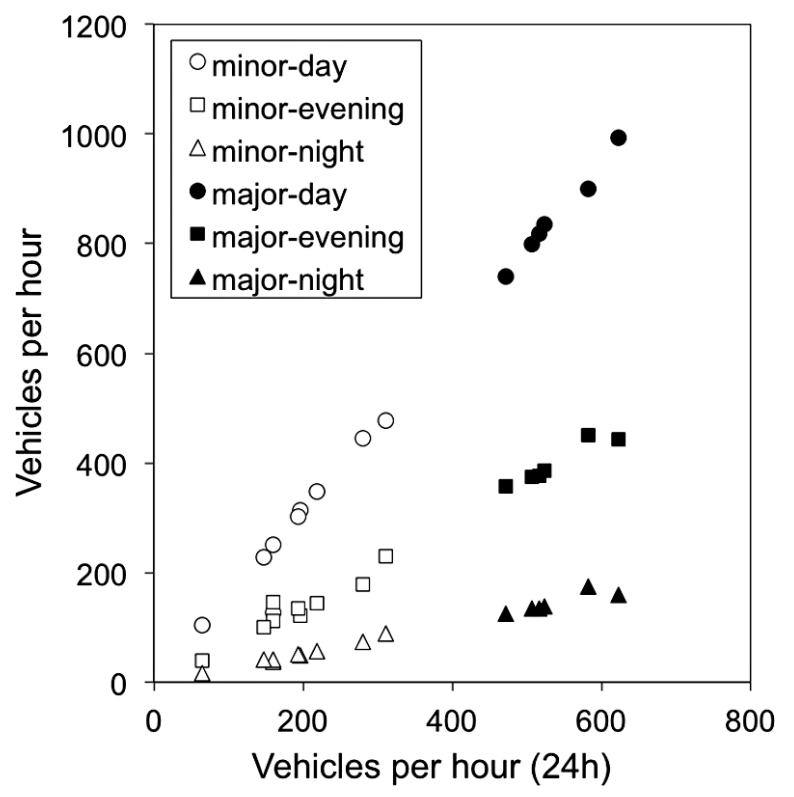


In two other partially overlapping datasets comprising 539 and 461 birds respectively, we analyzed the relationships between road mortality, and body mass and sex ratio. These Barn Owls were collected as road victims by volunteers from 1986 through 2013, and many owls were of unknown origin and age because they were not ringed. Birds were sexed based on inspection of their reproductive organs and plumage characteristics (De Jong and Van den Burg 2014). Body mass of road victims was compared with body mass of live owls trapped in their nest box during standard nest box monitoring and bird ringing, in both the provinces of Friesland and Flevoland. The standard nest box monitoring program of the Barn Owl Work Group Friesland also provided the data on Barn Owl reproduction.

\section{Statistics}

Frequency data were tested using Chi-squared analysis. Correlations were tested by Pearsons's test for correlation. Statistical significance was accepted at $\mathrm{p}<0.05$.

To investigate whether road casualties occur clustered at particular bottlenecks we compared the observed distribution of dead Barn Owls with random distribution models for major and minor roads. To obtain the random spatial distribution of owl mortality, the distribution of dead owls $(\mathrm{N}=186$ for major roads, and $\mathrm{N}=72$ for minor roads) was modeled 10 times over the total stretch of primary road $(71.7 \mathrm{~km})$ and secondary road $(102.5 \mathrm{~km})$. To allocate a dead owl to a particular part of the investigated road stretch, these were subdivided into $100 \mathrm{~m}$ sections. Based on the actual and modeled data we investigated the relationship between the percentage of road track and percentage of owl mortality, in the order of hectometer sections showing declining owl mortality. The modeled data include standard deviations (SD; $1.645 \times \mathrm{SD}$ is considered as $95 \%$ confidence limit).

\section{RESULTS}

\section{Relationships with owl population characteristics}

Of all reported birds that had hatched in Friesland and fell victim to traffic $(\mathrm{N}=994)$, more than $70 \%$ died in their first year of life and $15 \%$ in their second year (Fig. 5). Mortality by traffic was highest in autumn and winter and was the lowest in the breeding season when most of the females were on the nest site and males hunted in a small home range (Ramsden 2009). Throughout the year, the sex ratio did not differ from unity (232 males, 229 females), although there was a slight preponderance of male victims during the breeding season and of females in the autumn. Nearly $80 \%$ of the road victims were found within a radius of 25 $\mathrm{km}$, and $50 \%$ within $15 \mathrm{~km}$, of their birth site $(\mathrm{N}=994$; Fig.6). Birds found freshly dead as road victims had on average a lower body mass than live owls caught in nest boxes (Wilcoxon; $\mathrm{m}$ [dead owls $]=192, \mathrm{n}$ [live owls] $=347, \mathrm{R}_{\mathrm{s}}=32247, \mathrm{p}<0.001$; Fig. 7). However, the overlap in body mass between live and dead birds was considerable, and therefore we conclude that owls in any body condition were killed by traffic.

Although one might expect a positive relationship between the number of fledglings in a $5 \times 5 \mathrm{~km}$ block and the number of victims (because most casualties were close to the natal site), this is not what we found (Fig. 8). Overall, there was no significant linear correlation, but $5 \times 5 \mathrm{~km}$ blocks showing elevated mortality $(>10$ road kills between 1994 and 2009) showed an optimum curve in the number of road victims as a response to young production. Obviously, areas that produce few young will have relatively low numbers of road victims. More surprisingly, low numbers of road casualties were also found for the most productive owl areas in Friesland.

Fig. 5. Frequency distribution of age after hatching of Barn Owls (Tyto alba) killed along roads $(\mathrm{N}=994)$. Most traffic victims were within their first year of life and $12 \%$ lived for more than 40 months after hatching (not in the graph).

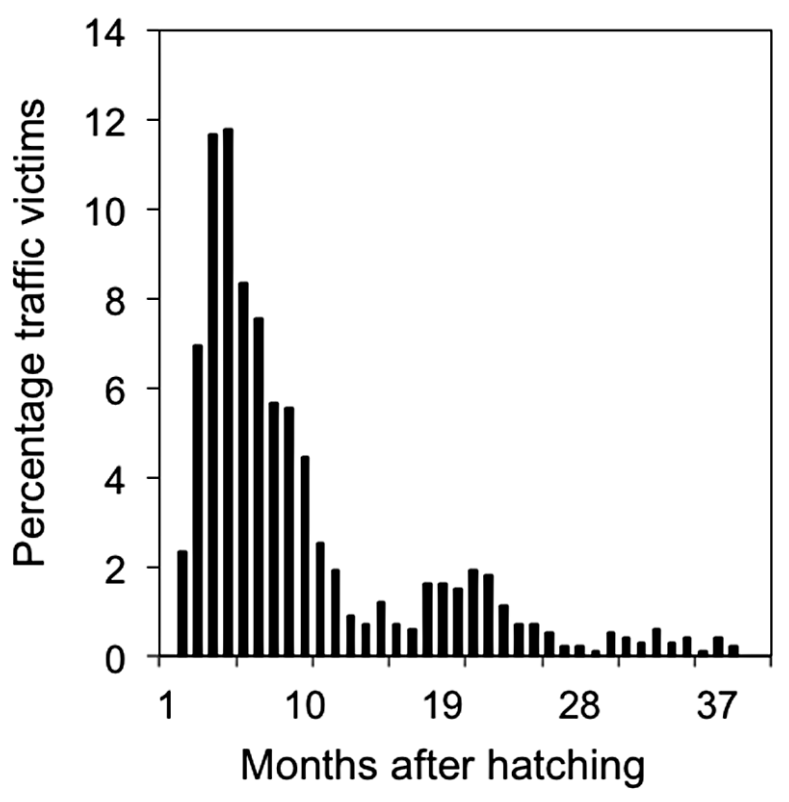

Fig. 6. The distance between hatching site and location where a bird was found dead $(\mathrm{N}=994)$. Fifty percent of all casualties occurred within $15 \mathrm{~km}$ from their natal nest site.

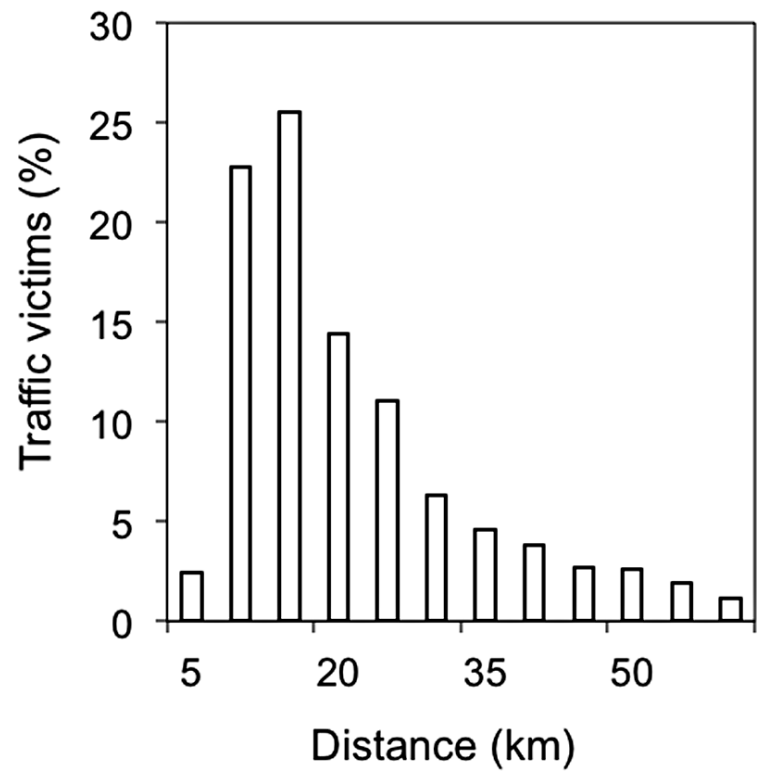


Fig. 7. The body mass of road victims compared with live Barn Owls (Tyto alba). Although the overlap is considerable, road victims had on average a lower body mass (Wilcoxon; $\mathrm{m}$ [dead owls] = 192, $\mathrm{n}$ [live owls] $\left.=347, \mathrm{R}_{\mathrm{s}}=32247, \mathrm{p}<0.001\right)$.

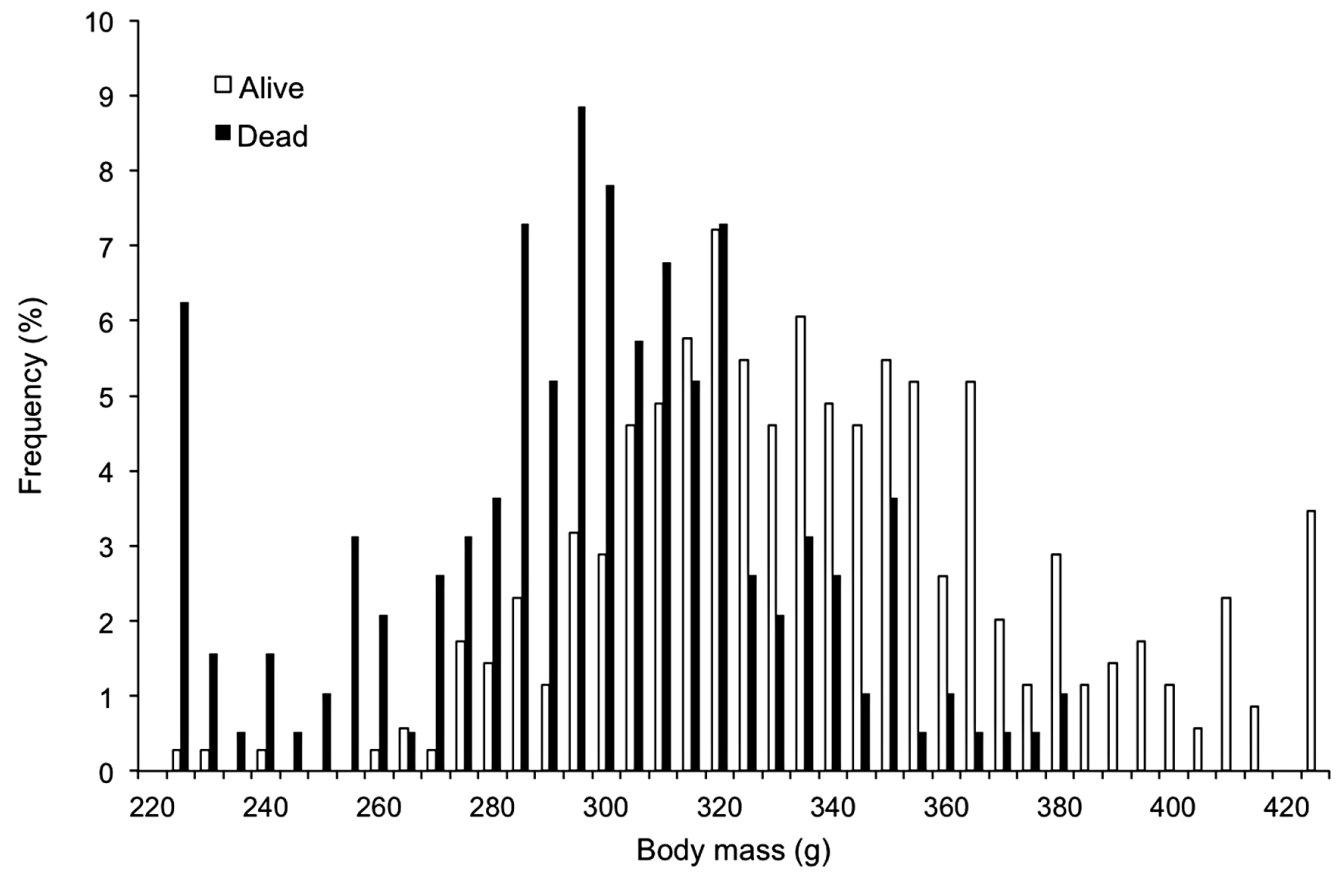

Because Barn Owls not only differ in productivity between regions but also between good and poor vole years (De Bruijn 1994, Taylor 1994, De Jong 1995), we analyzed the relationship between the number of young per pair per year (as indicator of yearly variation in food availability, irrespective of population size) and

Fig. 8. Relationship between the number of young produced per $25 \mathrm{~km}^{2}$ and the number of road casualties. Contrary to expectation, there was no positive correlation (further explanation in the text).

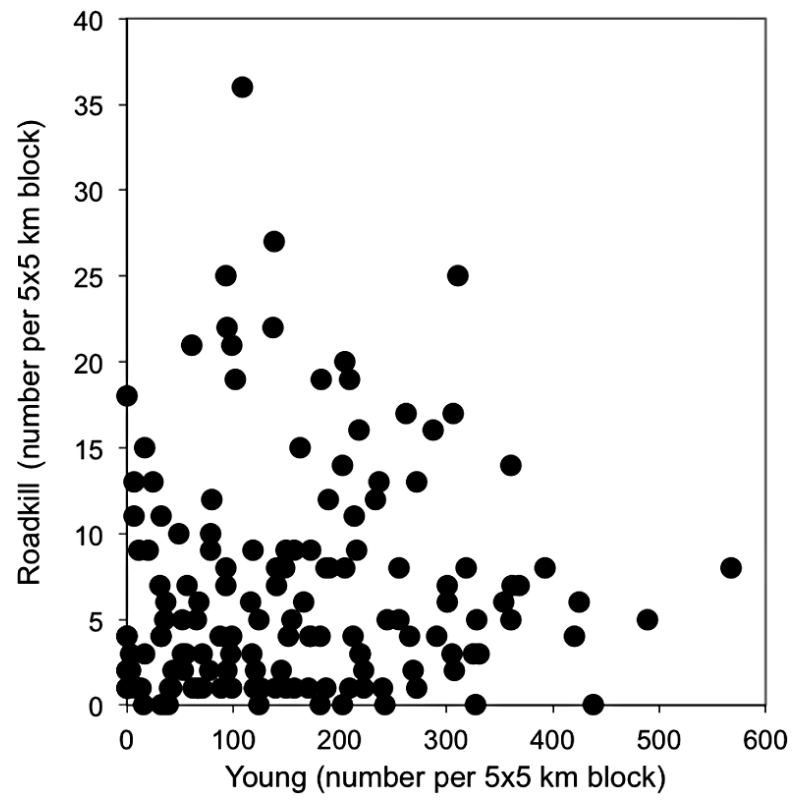

the number of young killed along roads proportionally to total young production per year. In years of high owl productivity, road mortality was strongly reduced (Pearson correlation test; $\mathrm{N}=16$ [1994-2009], $\mathrm{r}^{2}=0.48, \mathrm{t}_{\mathrm{s}}=3.59, \mathrm{p}<0.01$; Fig. 9).

Fig. 9. Relationship between nest success (expressed as the average number of young per pair per year) and the number of roadkill (expressed as the total yearly death toll as a fraction of the total number of young that is produced). In years of high nest success, traffic mortality is less intense (Pearson correlation test; $\mathrm{N}=16$ [1994-2009], $\mathrm{r}^{2}=0.48$, ts $\left.=3.59, \mathrm{p}<0.01\right)$.

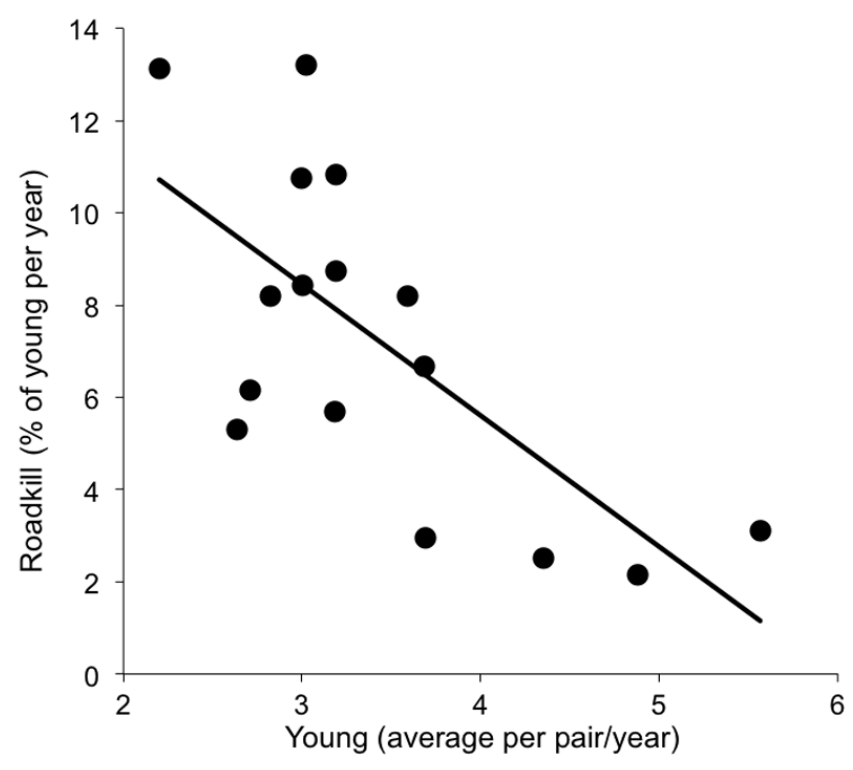




\section{Road characteristics}

The number of road victims on major roads was significantly higher than on other road types (Chi-squared; expected values: victims equally distributed per $\mathrm{km}$ major and minor or country road; $p<0.00001$; Table 1 ). With an increase in the amount of primary road ( $\mathrm{km}$ per $5 \times 5 \mathrm{~km}$ block) the number of roadkill also increased (Pearson correlation test; $\mathrm{N}=150, \mathrm{r}^{2}=0.43, \mathrm{t}_{\mathrm{s}}=10.5$, $\mathrm{p}<0.001$, Fig. 10). Such a positive significant relationship was not found for minor roads.

All owl mortality on major roads was observed within $5 \%$ of the total road length (Fig. 11); on minor roads within 7\%. This was significantly less than could be expected on the basis of random modeling, indicating that clustering does occur. Clustering on major roads happened in about $5 \%$ of total road length (from which there are parallel lines between actual and modeled data in Fig. 12), and on $1.5 \%$ of the minor roads.

Table 1. Number of road deaths of ringed Barn Owls (Tyto alba) in Friesland on major roads, minor roads, and country roads in the period 1994-2009 ( $\mathrm{N}=996)$. Road length is the total for the entire Province of Friesland. Most Barn Owl victims occur at major roads (corrected for road length, major and minor road comparison Chi-squared yields $\mathrm{p}<0.00001$ ). Because total road length of country roads is unknown, an average for owl mortality per $\mathrm{km}$ country road cannot be provided.

\begin{tabular}{lcccc}
\hline \hline & $\begin{array}{c}\text { Dead owls } \\
(\mathrm{N})\end{array}$ & Length $(\mathrm{km})$ & Per year & Per km \\
\hline Major roads & 467 & 205 & 29.18 & 0.142 \\
Minor roads & 291 & 482 & 18.18 & 0.038 \\
Country roads & 238 & $>>4000$ & 14.87 & \\
& & & & \\
\hline
\end{tabular}

Fig. 10. Relationship between the amount of primary road per $25 \mathrm{~km}^{2}$ and the number of road casualties. The more primary road is present, the more roadkill can be expected (Pearson correlation test; $\mathrm{N}=150, \mathrm{r}^{2}=0.43$, ts $\left.=10.5, \mathrm{p}<0.001\right)$.



Fig. 11. Relationship between the fraction of road that is responsible for all owl mortality on primary roads and secondary roads. Also presented are the modeled relationships on the basis of random distribution of all deceased owls (+/$\mathrm{SD})$. Because there is significant deviance between the observed and modeled outcomes (1.645 x SD), we conclude that on both primary roads and secondary roads clustering of road casualties occurs.



Fig. 12. Distributions of road typology with and without owl victims. There are no statistical differences in terms of verge width (A), herb cover (B), central divide width (C), and landscape type $(\mathrm{D}$; landscape types indicated in the text according to De Jong 2009; Chi squared yields for all comparisons $\mathrm{p}>0.1$ ).
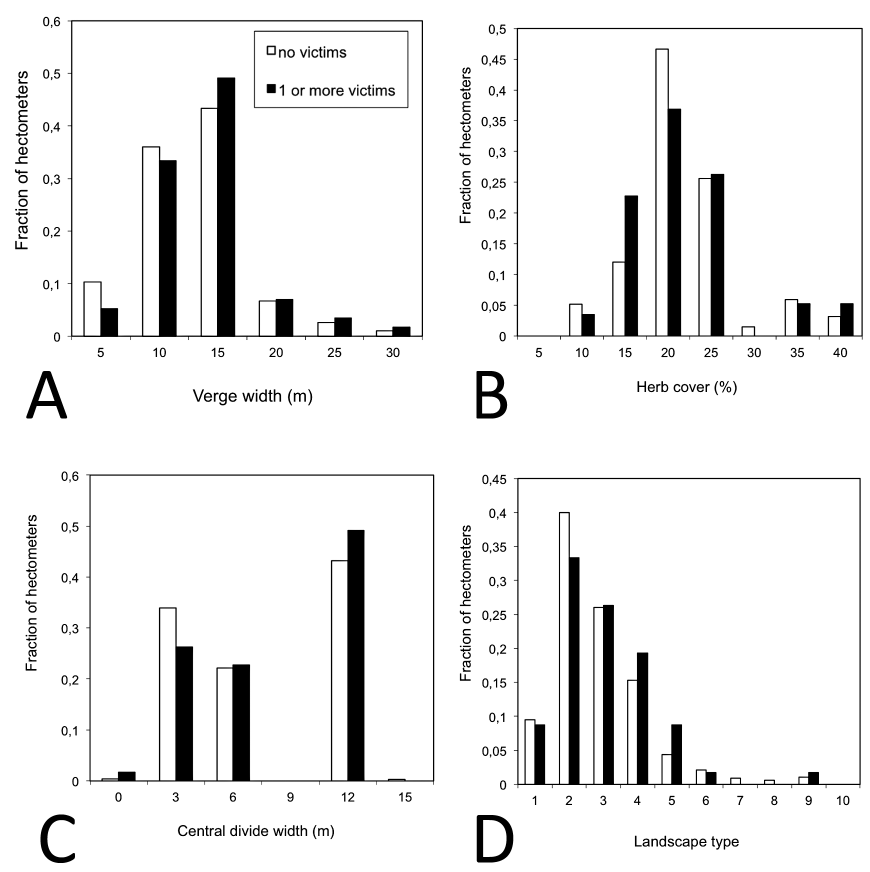
Of all other road characteristics, only the presence of major road junctions and major-minor road junctions contributed significantly to owl mortality clustering (Tab. 2; Fig. 12). For example, among the total stretch of road, $15 \%$ was at major road junctions. Among the road sections from where at least one owl casualty was reported, major road junctions made up 37\% (Chisquare, $\mathrm{p}<0.001$; Table 2). Other parameters (Fig. 12) show similar distributions among road sections with and without owl victims (Chi-square, $\mathrm{p}>0.1$ ).

Table 2. Percentages of road sections with a particular feature within the total number of road sections and among road sections at which at least one owl was found dead. Only major road junctions and junctions between major and minor roads stand out as death traps for Barn Owls (Tyto alba).

\begin{tabular}{lccc}
\hline \hline Feature & road (\%) & road with victims (\%) & $\mathrm{p}$ \\
\hline Major road junctions & 15 & 37 & 0.000 \\
Major-minor road & 33 & 51 & 0.003 \\
junctions & & & \\
Hedges & 43 & 42 & 0.875 \\
Dikes & 39 & 37 & 0.689 \\
Meadows & 93 & 91 & 0.578 \\
Crop fields & 16 & 14 & 0.647 \\
\hline
\end{tabular}

\section{DISCUSSION}

The Barn Owl population in Friesland (and the Netherlands) has increased spectacularly from the 1970s onward, despite the increase of road traffic and associated road mortalities (De Jong 2009). One might conclude that traffic victims have hardly been a problem for the Barn Owl population. However, without traffic mortality, the growth of the Barn Owl population may have been faster and the overall population more resistant to adverse conditions, like cold winters with long periods of snow cover. Also, when owls are not killed by traffic, more individuals may wander larger distances and reinforce populations that are still in a build-up phase, and new areas may be occupied. Of course, we have only been able to do the analyses presented in this paper because Barn Owls have become so numerous that you can get good sample sizes picking up road victims. Finally, if we have identified problems in road design for Barn Owls, we have to ask ourselves what the implications are for other species, which may be rare or on the decline, such as red-listed Short-eared owl (Asio flammeus) and Long-eared owl (Asio otus), respectively.

Road verges present good habitat for small rodents, and hence for hunting owls. The relationship between owl casualties and food provisioning appears from our analyses in several ways. The main question is whether the owls prefer to hunt along roads or whether they would avoid this if they have other suitable hunting habitat. Young birds that seek easy meals may be more attracted to hunt along roads compared to more experienced adult birds. However, adult birds may also have learned to hunt along roads whilst avoiding traffic collisions, based on previous experiences. Birds of lower body weight may be more desperate to catch prey, and take more risks hunting along roads. On the contrary, heavier birds that hunt along roads may be more careful to avoid collisions. This seems less likely though because birds in good condition also fall victim to traffic. Anyway, these observations cannot answer this main question.
We are tempted to conclude that road verges are not strongly favored foraging habitats of Barn Owls, because in years or areas of high young production there is no increase in traffic mortality. Moreover, in good vole years traffic casualties are strongly reduced. If prey is available in suitable amounts in the fields, hunting along road verges, and hence mortality, decreases. So, the first problem for the owls are not the roads themselves, but the lack of sufficient foraging habitat within the setting of lands used for (intensive) agriculture. Obviously, this is a problem for other species too, such as the Long-eared owl.

The highest density of owl road victims was found along major roads (cf. Bishop and Brogan 2013). An increase in major road kilometers is likely to result in more owl road victims because this relationship was strongly significant in Friesland. Other road types seemed less of a problem, either because the verges were less densely populated by small rodents, or traffic moved slower, or traffic volume was less, making it easier for owls to anticipate and escape from traffic. The design and management of road verges will affect their suitability for hunting because, for example, field voles were absent from road verges that were less than four meters wide (Bellamy et al. 2000, Ramsden 2009).

In terms of road design, it is clear that major road junctions and junctions between major roads and minor roads are primary areas of owl mortality (cf. Bishop and Brogan 2013). It may be that at such intersections owls cross roads more regularly because there are often unmanaged grasslands associated with such junctions, which may be rich in small mammals. Also, there are often overpasses at such junctions, which provide steep variation in elevation and rodent-rich banks that suddenly give way to the major road. These junctions make up only a small proportion of the total amount of major road kilometers, and thus may make it feasible to take site-specific measures to prevent owl-traffic collisions. Experiments on road design adjustments focusing on alteration of the owls' hunting behavior at major road junctions are currently underway in Friesland.

To reduce owl traffic victims, the best option is to adopt policies and management to improve the quality of Dutch farmlands in such a way that it can support large populations of small rodents. Besides voles, mice, and Barn Owls such measures are likely to be beneficial to the total agro-biodiversity.

Responses to this article can be read online at: http://www.ace-eco.org/issues/responses.php/1201

\section{Acknowledgments:}

The voluntary fieldwork of the enthusiastic Frisian ringers Willem Louwsma, Anne van der Wal, Romke van der Veen en Janco Mulder made this study possible. We are very grateful to the volunteers of the Werkgroep Kerkuilen Nederland (Working Group Barn Owls Netherlands) and specially Stef Waasdorp, who collected many road victims. We wish to thank Hugh Jansman, Stef Waasdorp, and David Johnson for their valuable comments on earlier versions of this manuscript. The Province of Friesland and the Ministry of Infrastructure and the Environment kindly provided traffic counts on Frisian roads. 


\section{LITERATURE CITED}

Bairlein, F. 1985. Desmigration und Sterblichkeit in Süddeutschland beringter Schleiereulen (Tyto alba). Vogelwarte 33:81-108.

Barnes, M. D. 1936. The death-toll of birds on our roads. NaturalistL: $85-86$

Baudvin, H. 1997. Barn Owl (Tyto alba) and Long Eared Owl (Asio Otus) mortality along motorways on Bourgogne-Champagne: report and suggestions. Pages 58-61 in J. R. Duncan, D. H. Johnson, and T. H. Nicholls, editors. Biology and conservation of owls of the Northern Hemisphere: 2nd international symposium. General Technical Report NC-190. U.S. Forest Service, North Central Forest Experiment Station, St. Paul, Minnesota, USA.

Bellamy, P. E., R. F. Shore, D. Ardeshir, J. R. Treweek, and T. H. Sparks. 2000. Road verges as habitat for small mammals in Britain. Mammal Review 30(2):131-139. http://dx.doi.org/10.1046/ j.1365-2907.2000.00061.x

Bishop, C. A., and J. M. Brogan. 2013. Estimates of avian mortality attributed to vehicle collisions in Canada. Avian Conservation and Ecology 8(2):2. http://dx.doi.org/10.5751/ACE-00604-080202

Bourquin, J. D. 1983. Mortalité des rapaces de long de l'autoroute Geneve-Lausanne. Nos Oiseaux 37:149-169.

De Bruijn, O. 1994. Population ecology and conservation of the Barn Owl (Tyto alba) in farmland habitats in Liemers and Achterhoek. Ardea 82:1-109.

De Jong, J. 1983. De Kerkuil. Kosmos, Utrecht, The Netherlands.

De Jong, J. 1995. De Kerkuil en andere in Nederland voorkomende uilen. Friese Pers Boekerij, Leeuwarden, The Netherlands.

De Jong, J. 2009. The recovery of the Barn Owl (Tyto alba) in Friesland, northern Netherlands: population growth in relation to landscape features. Ardea 97:445-452. http://dx.doi. org/10.5253/078.097.0407

De Jong, J., and J. Paulusma. 1996. De Kerkuil als verkeersslachtoffer. Vanellus 49:142-147.

De Jong, J., and A. van den Burg. 2014. A new method to sex Barn Owls (Tyto alba). Ardea 100:95-97. http://dx.doi.org/10.5253/078.100.0114

Dekker, J. J. A., and H. Bekker. 2010. Badger (Meles meles) road mortality in the Netherlands: the characteristics of victims and the effects of mitigation measures. Lutra 53(2):81-92.

Erritzoe, J., T. D. Mazgajski, and Ł. Rejt. 2003. Bird casualties on European roads - a review. Acta Ornithologica 38:77-93. http://dx. doi.org/10.3161/068.038.0204

Huijser, M. P. 2000. Life on the edge. Hedgehog traffic victims and migration strategies in an anthropogenic landscape. Dissertation. Wageningen University, Wageningen, The Netherlands.

Illner, H. 1992. Road deaths of Westphalian owls: methodological problems, influence of road type and possible effects on population levels. Pages 94-100 in C. A. Galbraith, I. R. Taylor, and S. Percival, editors. The ecology and conservation of European owls. Proceedings of a symposium held at Edinburgh University. UK Nature Conservation, Peterborough, UK.

Kociolek, A. V., A. P. Clevenger, C. C. St. Clair, and D. S. Proppe. 2011. Effects of road networks on bird populations. Conservation Biology 25:241-249. http://dx.doi.org/10.1111/j.1523-1739.2010.01635. $\mathrm{x}$

Loss, S. R., T. Will, and P. P. Marra. 2014. Estimation of birdvehicle collision mortality on U.S. roads. Journal of Wildlife Management 78:763-771. http://dx.doi.org/10.1002/jwmg.721

Marti, C. D., and P. W. Wagner 1985. Winter mortality in Common Barn-Owls and its effect on population density and reproduction. Condor 87:111-115. http://dx.doi.org/10.2307/1367142

Massemin, S., Y. Le Maho, and Y. Handrich. 1998. Seasonal patterns in age, sex, and body condition of Barn Owls Tyto alba killed on motorways. Ibis 140:70-75. http://dx.doi.org/10.1111/ j.1474-919X.1998.tb04543.x

Newton, I., I. Wyllie, and L. Dale. 1997. Mortality causes in British Barn Owls (Tyto alba) based on 1,101 carcasses examined during 1963-1996. Pages 299-307 in J. R. Duncan, D. H. Johnson, and T. $\mathrm{H}$. Nicholls, editors. Biology and conservation of owls of the Northern Hemisphere: 2nd international symposium. General Technical Report NC-190. U.S. Forest Service, North Central Forest Experiment Station, St. Paul, Minnesota, USA.

Ramsden, D. 2009. Barn Owls and major roads: results and recommendations from a 15-year research project. The Barn Owl Trust, Ashburton, UK.

Rodts, J., L. Holsbeek, and S. Muyldermans. 1998. Dieren onder onze wielen. Koninklijk Belgisch Verbond voor de Bescherming van Vogels, Brussels, Belgium.

Smit, G. F. J., G. J. Brandjes, and A. J. M. Meijer. 1998. Faunaverkeersslachtoffers rijkswegen Noord-Nederland. Rapport nr. 97.35. Bureau Waardenburg bv, Culemborg, The Netherlands.

Taylor, I. R. 1994. Barn Owls: predator prey relationships and conservation. Cambridge University Press, Cambridge, UK.

Uhlenhaut, K. 1976. Unfälle von Schleiereulen durch Kraftfahrzeuge. Falke 23:56-60.

Van der Hut, R. M. G., J. de Jong, and E. R. Osieck. 1992. Biologie en bescherming van de Kerkuil (Tyto alba); aanzet tot het beschermingsplan. Technisch Rapport Vogelbescherming 7. Vogelbescherming Nederland, Zeist, The Netherlands.

Van der Tempel, M. W. 1993. Vogelslachtoffers door het wegverkeer. Technisch Rapport Vogelbescherming Nederland 11. Vogelbescherming Nederland, Zeist, The Netherlands.

Van Nieuwenhuyse, D., J. C. Génot, and D. H. Johnson. 2008. The Little Owl: conservation, ecology and behavior of Athene noctua. Cambridge University Press, Cambridge, UK.
Editor-in-Chief: Ryan Norris Subject Editor: André A.Dhondt
Sponsored by the Society of Canadian Ornithologists and Bird Studies Canada Parrainée par la Société des ornithologistes du Canada et Etudes d'oiseaux Canada

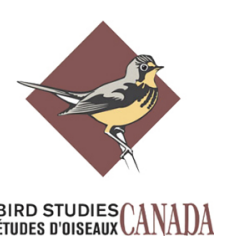

